\title{
Pengaruh Menonton Video Tentang 'Corona' dari Bintang Emon terhadap Perilaku Social Distancing Mahasiswa FPSB UII
}

\author{
The Effects of Watching Video About 'Corona' From \\ Bintang Emon on Social Distancing Behavior of \\ Indonesian Islamic University Faculty Psychology and \\ Social-cultural Students.
}

\author{
Rachmat Arya Prayuda', Puji Hariyanti² \\ 1,2 Program Studi Ilmu Komunikasi, Universitas Islam Indonesia, Sleman \\ Yogyakarta, Indonesia
}

\section{Author's email: \\ 117321137@students.uii.ac.id 2 puji.hariyanti@uii.ac.id}

\begin{abstract}
Bintang Emon uploaded a video containing complaints and an invitation to netizens to fight Corona on Twitter and Instagram. The video got quite a lot of attention from netizens. This study aims to determine the effect of videos about Corona from Bintang Emon on the social distancing behavior of students of the Faculty of Psychology and Socio-Cultural Sciences, Islamic University of Indonesia. This research is quantitative research with explanative type. This study shows that Bintang Emon's video has a positive and significant influence on the social distancing behavior of students of the Faculty of Psychology and Socio-Cultural Sciences, Islamic University of Indonesia. In the regression test, the results obtained a significance value of 0.02, which means $>0.05$ and the $t$-count value of $3.144>$ from the t-table which is worth 1.988. These results show that there is an influence given by the variable watching videos about Corona' from Bintang Emon on the social distancing behavior of FPSB UII students.
\end{abstract}

Keywords: Corona, Effect, Social Media, Social Distancing.

Bintang Emon mengunggah video yang berisikan keluh kesah serta ajakan kepada netizen untuk melawan Corona di Twitter dan Instagram. Video itu mendapatkan perhatian netizen cukup besar. Penelitian ini bertujuan untuk mengetahui pengaruh video tentang Corona dari Bintang Emon terhadap perilaku social distancing Mahasiswa Fakultas Psikologi dan Ilmu Sosial Budaya Universitas Islam Indonesia. Penelitian ini merupakan penelitian kuantitatif dengan jenis eksplanatif. Penelitian ini menunjukkan bahwa video Bintang Emon memberikan pengaruh positif dan signifikan terhadap perilaku social distancing Mahasiswa Fakultas Psikologi dan Ilmu Sosial Budaya Universitas Islam Indonesia. Pada uji regresi, didapatkan hasil nilai signifikansi sebesar 0,02 yang artinya > 0,05 dan nilai t hitung sebesar $3.144>$ dari t tabel yang bernilai 1.988. Hasil ini menunjukkan adanya pengaruh yang diberikan variabel menonton video tentang Corona' dari Bintang Emon terhadap perilaku social distancing Mahasiswa FPSB UII

Kata kunci: digital, komunikasi pemasaran, amazara 


\section{PENDAHULUAN}

Pada 11 Maret 2020, WHO mengumumkan bahwa Coronavirus dinyatakan sebagai pandemi. Coronavirus yang dinyatakan sebagai pandemi adalah jenis terbaru yang diberi nama SARS-CoV2 dan biasa disebut dengan Covid-19. Hingga Maret 2020, virus yang bermula di kota Wuhan Cina tersebut telah menyebar ke 118 negara. Di Indonesia, Presiden Jokowi meminta masyarakat untuk mengurangi mobiltas bepergian dari satu tempat ke tempat lain guna menghambat laju penyebaran virus Covid-19. Presiden Joko Widodo juga menekankan tindakan pembatasan sosial atau Social Distancing dalam Press Release.

Social Distancing pada dasarnya adalah menghindari atau menjaga jarak antar-masyarakat yang berpotensi melakukan kontak langsung. Konsep ini menjelaskan bahwa setiap orang harus menjaga jarak paling tidak dua meter, mengusahakan tidak melakukan kotak langsung, dan menghindari pertemuan massal (Buana, 2020). Covid-19 sangat mudah sekali menular terutama melalui percikan liur dari orang yang terinfeksi dan social distancing dinilai efektif untuk menghindari hal-hal semacam itu.

Wilder-Smith dan Freedman (2020) mengatakan bahwa isolasi, karantina, dan pembatasan komunitas merupakan tiga bentuk upaya pencegahan penularan wabah penyakit seperti pandemi. Isolasi merupakan upaya memisahkan orang sakit terhadap penyakit atau orang sakit dengan orang sehat. Karantina adalah pembatasan orang yang diduga terpapar penyakit terhadap orang lain, yang mana orang yang diduga terpapar dapat dikatakan masih dalam pada tahap inkubasi. Pemabatasan sosial adalah bentuk upaya membatasi kegiatankegiatan sosial dalam skala komunitas seperti contohnya tidak ada pertemuan publik, penutupan tempat kerja, hingga penutupan sekolah.

Bukan hanya pemerintah, masyarakat atau netizen juga turut mengkampanyekan gerakan social distancing di sosial media. Media Sosial sendiri adalah sebuah media online dimana para penggunanya dapat berpartisipasi, berbagi, menciptakan isi dalam jejaring sosial (Watie, 2015). Menurut Kementerian Komunikasi dan Informatika, 95\% dari 63 juta orang pengguna internet di Indonesia menggunakan internet untuk mengakses jejaring sosial. Hal ini membuat media sosial menjadi efektif untuk menyebarkan informasi.

Di media sosial, cukup banyak konten berbentuk video yang berisikan informasi atau edukasi mengenai social distancing. Salah satunya adalah video yang diunggah oleh seorang komika (sebutan buat pekerja stand up comedy) yang bernama Bintang Emon. Bintang Emon mengunggah sebuah video yang berunsur komedi di akun sosial media miliknya yang bertema Corona. Dalam video tersebut, Bintang Emon menyampaikan pesan untuk tidak meremahkan Corona dan melakukan anjuran pencegahan virus corona dengan ekspresi yang menunjukkan kekesalan.

Bintang Emon mengunggah video bertema Corona pada 22 Maret 2020. Video tersebut meraih lebih dari 7 juta likes dan 37 ribu komentar di Instagram, sedangkan di Twitter telah meraih 129 ribu retweet dan 188 ribu likes. Angka tersebut merupakan angka yang besar untuk konten di media sosial Indonesia. Selain angka yang fantastis tersebut, Bintang Emon juga mendapatkan banyak pujian dari netizen Indonesia untuk video tersebut. 
Bintang Emon yang terkenal sebagai influencer dengan DPO-nya (Dewan Perwakilan Omel-omel) membuat video tentang Corona yang mewakili keluh kesah masyarakat yang resah karena masih banyak orang yang melanggar peraturan PSBB. Tentu saja, sebagian besar masyarakat merasa resah ketika mengetahui masih banyak orang yang melanggar peraturan PSBB sementara masyarakat yang mematuhi peraturan PSBB harus merelakan beberapa kegiatan mereka dilakukan dengan daring atau bahkan ditunda. Bintang Emon mengunggah video DPO tentang Corona di akun instagram dan twitter pribadinya dengan tagar istimewa yaitu \#DPOCorona.

Video DPO tentang Corona dari Bintang Emon menjadi menarik karena cara penyampaian pesan oleh Bintang Emon di video ini menarik perhatian banyak orang. Video tentang Corona dari Bintang Emon ini ditujukan untuk mengikatkan orang untuk bersama-sama patuh dengan arahan social distancing guna melawan penyebaran Virus Covis-19. Bintang Emon dengan latar belakangnya adalah seorang komika, memberikan nilai yang berbeda terhadap video yang dibuatnya karena selain pesan yang ada dalam video tersebut ditujukan untuk mengajak masyarakat melakukan upaya social distancing, penonton video tersebut juga merasa terhibur dengan cara pembawaan pesan oleh Bintang Emon yang lucu. Hal ini menjadi daya tarik yang berbeda dari sekian banyak jenis konten atau informasi kepada masyarakat dalam menghadapi pandemi Covid-19.

Pada saat Virus Corona menjadi pandemi dan masuk ke Indonesia, mayoritas mahasiswa dan mahasiswi melaksanakan kegiatan belajar mengajar secara daring dengan menggunakan gadget pribadi masing-masing. Intensitas mahasiswa menggunakan gadget semakin meningkat. Universitas Islam Indonesia menjadi salah satu universitas yang melaksanakan kegiatan belajar daring selama pandemi Virus Corona. Pada Fakultas Psikologi dan Ilmu Sosial Budaya (FPSB), intensitas para mahasiswa mengakses sosial media semakin meningkat dikarenakan banyaknya aktivitas pembelajaran yang berhubungan dengan sosial media. Dengan meningkatnya aktivitas di sosial media, terpaan informasi yang diterima mahasiswa FPSB juga akan meningkat termasuk informasi tentang virus Corona.

Ada beberapa penelitian yang telah dikerjakan terutama terkait dengan dampak-dampak media sosial. Riris (2019), misalnya, menggunakan HBM (Health Belief Model) sebagai kerangka utama penelitiannya. Hasilnya adalah adanya pengaruh dari terpaan Web-series Berjudul Sore - Istri dari Masa Depan Terhadap Kesadaran Pencegahan Diabetes Milletus Pada Usia Muda. Web-series Berjudul Sore - Istri dari Masa Depan merupakan produksi dari Tropicana Slim yang diunggah di YouTube.

YouTube merupakan salah satu platform digital di mana masyarakat digital (netizen) dapat mengunggah informasi berbentuk video dan berinteraksi di sana. Kemajuan teknologi digital memungkinkan masyarakat menyebarkan informasi untuk mempengaruhi masyarakat dengan sangat cepatnya.

Berbeda dengan penelitian sebelumnya, penelitian ini dilakukan untuk mengkaji adakah pengaruh menonton video Bintang Emon tentang 'corona' terhadap perilaku social distancing mahasiswa Fakultas Psikolagi dan Ilmu Sosial Budaya Universitas Islam Indonesia.

\section{LANDASAN TEORI}

Media baru pada dasarnya merupakan media yang menawarkan banyak hal seperti pengembangan jaringan, interaksi, konvergensi, dan lain- 
lain yang mana berkaitan dengan pembuatan dan penyampaian pesannya. Media baru memungkinkan penggunanya memiliki kesempatan untuk memilih informasi yang ingin dikonsumsi dari banyak sekian informasi dan memegang kendali atas keluaran informasi sesuai dengan apa yang diinginkan. Konsep yang lebih interaktif dan bebas inilah yang menjadi pemahaman dasar dari media baru.

Menurut Bettinghaus (Putri, dkk., 2015), persuasi adalah suatu usaha untuk memengaruhi pikiran dan perilaku seseorang atau dapat dijelaskan dengan interaksi antara pembicara dan pendengar dimana pembicara berusaha mempengaruhi perilaku pendengar melalui perantara pendengaran dan penglihatan. Dalam komunikasi, pesan persuasi sendiri adalah usaha yang dilakukan oleh komunikator yang bertujuan untuk memengaruhi perilaku komunikan atau pendengar sesuai dengan apa yang diharapkan oleh sang komunikator.

Media sosial seperti Facebook, Instagram, dan Twitter yang merupakan bagian dari media baru dimana pesan persuasif dapat diaplikasikan. Pamungkas (2013) mengatakan bahwa media sosial merupakan media yang sangat populer untuk melakukan segala macam bentuk komunikasi, termasuk komunikasi dalam bentuk pesan persuasif. Konten di media sosial sangat mudah disebarluaskan atau didistribusikan ke berbagai tujuan dengan format yang berbeda-beda. Hal ini dikarenakan datanya yang berbentuk digital.

Dengan hadirnya internet, akses menggunakan media menjadi semakin mudah. Internet sendiri sudah menjadi bagian kehidupan sehari-hari masyarakat. Dengan demikian, interkasi antara khalayak dan media pun semakin sering terjadi. Internet memungkinkan masyarakat mengakses berbagai jenis platform dengan sangat mudah termasuk platform berbentuk video. Dengan demikian, terpaan media pun terjadi setiap harinya dalam berbagai macam bentuk.

Menurut Rakhmat (dalam Khoiriyah, 2019: 5), terpaan media adalah suatu perilaku seorang atau beberapa orang (audiens) dalam menggunakan media. Maksud terpaan media adalah bagaimana seseorang diterpa oleh informasi yang serupa dari media atau bagaimana media menerpa seseorang dengan pesan informasi. Penggunaan media sendiri terdiri dari waktu yang diluangkan untuk media, apa jenis media yang digunakan, dan apa hubungan antara orang yang mengkonsumsi media dengan media itu sendiri.

Menurut Elvinaro (dalam Khoiriyah, 2019: 6), mengukur terpaan media dapat dilakukan melalui 3 indikator.

- Frekuensi. Seberapa sering seseorang menerima informasi yang diberikan oleh media. Semakin sering seseorang menerima sebuah pesan informasi maka semakin menempel pesan yang disampaikan dan perhatian akan menjadi lebih besar.

- Perhatian (atensi). Suatu proses mental dari seseorang untuk menyimak pesan yang diberikan oleh media. Misal dalam video unsur-unsur yang perlu disimak dengan cermat adalah bagaimana audio dan visualnya.

- Durasi. Seberapa lama waktu yang dihabiskan dalam menggunakan media atau menerima pesan dari media.

Mulyana (dalam Hamka, 2015) menjelaskan bahwa efek adalah kondisi dimana seorang individu atau khalayak saat setelah menerima pesan atau dampak pesan kepada indidividu atau khalayak tersebut. Kondisi ini dapat berupa bertambahnya pengetahuan, berubahnya 
sikap, dan melakukan tindakan atau perubahan perilaku.

Ada dua cara untuk memengaruhi perubahan perilaku terutama dalam hal kesehatan melalui media, yaitu secara langsung dan cara tidak langsung (Wakefield dkk, 2010). Cara langsung biasanya dengan mencoba memengaruh individu dengan melakukan pendekatan secara emosional. Hal ini dilakukan untuk memengaruhi keputusan perubahan perilaku ditingkat individu. Contoh cara langsung ini adalah kegiatan kampanye antirokok dengan menekankan bahaya merokok serta memberikan nomor telepon sebagai salurun komunikasi dukungan. Dengan cara-cara seperti ini, perubahan perilaku untuk mengambil keputusan memilih hidup sehat atau tidak bergantung langsung antara individu dan komunikator dalam menyampaikan pesan melalui media.

Selain secara langsung, perubahan perilaku kesehatan melalui media juga bisa dilakukan dengan cara tidak langsung. Cara tidak langsung memiliki tiga tahap. Tahap pertama adalah media mencoba membuat agenda untuk memerkuat frekuensi pesan atau kedalaman pesan atau bahkan keduanya. Dengan digabungkan dengan terpaan yang diterima individu, hal ini sangat efektif untuk memengaruhi perubahan perilaku baik menguat atau malah memburuk. Karena informasi seperti pesan pada kampanye kesehatan mencakup khalayak luas di media, persebaran pesan menjadi lebih cepat dan memungkinkan orangorang yang belum melihat pesan aslinya melalukan perubahan perilaku dikarenakan pengaruh lingkungan sosial yang terlebih dahulu menerima pesan utama melalui media. Tahapan terakhir, pesan seperti kampanye kesehatan dapat terseret menjadi diskusi publik dan dapat mendorong perubahan perilaku public hingga bahkan kebijakan public.
Schmied (2017) menjelaskan melalui model Stages of Changes, orangorang mengubah perilaku melalui 6 tahap sebagai berikut.

1) Pre-contemplation

Tahap dimana seseorang merasa perilaku yang dilakukannya tidak menimbulkan masalah (contoh : buang air di tempat yang terbuka atau yang tidak semestinya).

2) Contemplation

Tahap dimana orang mulai menyadari perilaku yang dilakukan dan mulai mempertimbangkan pro dan kontra (contoh: buang air di tempat yang terbuka meski khawatir dengan apa yang dilakukan).

3) Preparation

Tahap dimana orang mulai termotivasi untuk mengubah perilaku dan mulai mulai berencana dengan melihat manfaat (contoh: orang mulai yakin akan pentingnya fungsi toilet atau WC)

4) Action

Tahap dimana orang mulai mempraktikkan perilaku dan mengalami manfaat serta dampak-dampak lain (contoh: mulai menggunakan toilet dan melakukan perawatan secara rutin).

\section{5) Maintenance}

Tahap dimana orang merasa membutuhkan upaya untuk mempertahankan perilaku agar bersifat jangka panjang (contoh: orang mulai menggunakan alat pembersih dan menggunakannya dalam waktu yang lama serta rutin)

6) Termination

Tahap dimana orang tidak tergoda untuk berhenti mempraktikan perilaku dan 
mampu mempertahankannya dalam waktu panjang (contoh: rutin menggunakan alat pembersih dan menentang buang air di tempat yang tidak semestinya).

\section{METODE}

Penelitian ini menggunakan metode kuantitatif dengan jenis penelitian kuantitatif eksplanatif. Pada dasarnya, penelitian ini bertujuan untuk menemukan bagaimana hubungan antar-gejala. Dengan cara menyebarkan kuisioner kepada responden yang menjadi objek penelitian, akan didapat hasil statistik berupa angka yang akan dikalkulasikan sehingga dapat menyimpulkan bagaimana hubungan antara variabel. Kriyantono (2012) menjelaskan bahwa survei bertujuan untuk mengambul sampel dalam populasi yang dapat mewakilkan populasi yang dipilih. Hal ini bertujuan untuk mendapatkan data atau informasi dari responden yang mewakilkan populasi yang dipilih, Selain itu, penelitian survei merupakan penelitian yang terstuktur sehingga ada perencanaan mendetail yang pasti.

Survei dilakukan mulai 3 November - 2 Desember 2020 dengan cara menyebar kuesioner kepada Mahasiswa Aktif FPSB UII. Penyebaran kuesioner dilakukan dengan menggunakan Google Form. Dengan menggunakan rumus Slovin, sampel yang diambil adalah sebanyak 98 orang dari seluruh populasi Mahasiswa aktif FPSB UII. Data yang diperoleh dari responden merupakan data primer berbentuk jawaban responden terhadap butir kuesioner dalam skala likert. Selain itu, ada data sekunder yang digunakan dalam penelitian ini, yaitu berupa data yang diperoleh dari pihak kedua seperti kajian pustaka atau sumbersumber lain seperti internet.
Analisis data menggunakan analisis regresi linear sederhana. Analisis regresi linear sederhana dilakukan untuk mengetahui dan menjelaskan hubungan antara variabel independen (X) dan variabel dependen (Y). Penelitian ini menggunakan analisis regresi linear sederhana karena penelitian ini hanya memiliki satu variabel untuk masingmasing variabel independen dan varaibel dependen. Adapun rumus persamaan regresi yang didapatkan adalah sebagai berikut:

$\hat{\mathrm{Y}}=\mathrm{a}+\mathrm{bX}$

Keterangan:

$\hat{\mathrm{Y}}=$ Garis Regresi / Variabel Respon

$\mathrm{a}=$ Konstanta

$\mathrm{b}=$ Konstanta Regresi

$\mathrm{X}=$ Variabel Bebas

Selain itu, dilakukan juga uji validitas dan reliabilitas untuk menguji valid atau tidak kuesioner dan sebagai alat ukur indikator dari variabel. Selanjutnya, dilakukan uji $t$ (t-test). Uji t (t-test) dilakukan untuk membuktikan adanya pengaruh yang ditimbulkan dari variabel independen terhadap variabel dependen. Dalam uji ttest, kita dapat mengetahui apakah hipotesis kita diterima atau ditolak. Adapun hipotesis yang diajukan dalam penelitian ini adalah sebagai berikut.

HO : Tidak ada pengaruh menonton video Bintang Emon tentang 'corona' terhadap perilaku social distancing mahasiswa Fakultas Psikolagi dan Ilmu Sosial Budaya Universitas Islam Indonesia.

HA : Ada pengaruh menonton video Binteng Emon tentang 'corona' terhadap perilaku social distancing mahasiswa Fakultas Psikolagi dan Ilmu Sosial Budaya Universitas Islam Indonesia. 


\section{HASIL DAN PEMBAHASAN}

Video tentang 'Corona' dari Bintang Emon yang diunggah di media sosial pribadi miliknya merupakan keresahannya terhadap masyarakat yang tidak disiplin dalam melakukan upaya pencegahan penularan virus Covid-19. Bintang Emon yang sebelumnya sudah pernah membuat video DPO merasa setiap video DPO yang dibuatnya akan memberikan pengaruh atau reaksi dari netizen yang menonton video tersebut.

Video DPO tentang Corona menjelaskan bahwa keresahan Bintang Emon yang meremehkan penularan Virus Corona, diakhiri dengan ajakan untuk melawan bersama dalam menghadapi pandemi Covid-19 ini. Video yang diunggah Bintang Emon ini jelas merupakan suatu kemasan yang mengandung pesan persuasif. Pesan yang disampaikan dalam video tersebut berupa ajakan untuk mematuhi protokol dalam pencegahan penularan virus Covid-19, dan akan memberikan reaksi dari netizen yang menontonya.

Data hasil persebaran kuesioner kepada responden memberikan alasan yang cukup kuat untuk mengatakan bahwa video DPO tentang Corona yang diunggah Bintang Emon di media sosialnya merupakan pesan persuasif. Pada hasil data yang didapat dari kuesioner nomor 5, yaitu merasa video tentang corona dari Bintang Emon mengajak para followers atau penonton untuk mewaspadai dan tidak meremehkan virus corona mendapatkan total $93,9 \%$ responden memilih pernyataan setuju dan sangat setuju. Selain itu, pada hasil data yang didapat dari kuesioner nomor 6, yaitu merasa Bintang Emon mengajak atau menyeru para followers-nya untuk mengikuti protocol dan melakukan upaya social distancing melalui video tentang corona yang dibuatnya mendapatkan total 97\% responden memilih setuju dan sangat setuju. Kedua kueioner ini (kuesioner nomor 5 \& 6) merupakan kuesioner bagian dari indikator atensi.

Atensi sendiri merupakan suatu proses mental dari seseorang untuk menyimak pesan yang diberikan oleh media. Misalnya, dalam video unsur-unsur yang perlu disimak dengan cermat adalah bagaimana audio dan visualnya. Dengan data yang diperoleh dari kuesioner nomor 5 dan 6, hal ini dapat menjadi alasan yang kuat bahwa video tentang 'Corona' dari Bintang Emon memberikan pesan persuasif kepada responden yang menonton dengan tujuan untuk melakukan upaya social distancing dalam menghadapi pandemi Covid-19.

Pada indikator action, yaitu indikator yang menjelaskan tahap dimana orang mulai mempraktikkan perilaku dan mengalami manfaat serta dampak-dampak lain mendapat hasil yang sangat bagus. Perolahan total responden (kuesioner nomor 12, 13, 14, 15) yang memilih setuju dan sangat setuju menunjukkan angka $98 \%, 86,7 \%, 89,8 \%$, dan $72,5 \%$ berturutturut menjelaskan tentang menggunakan masker, mengatur jarak, menggunakan hand sanitizer, dan membersihkan barang.

Data ini menunjukkan angka yang signifikan untuk menggambarkan tindakan langsung para responden dala upaya social distancing. Pada kuesioner nomor 13, kuesioner menjelaskan tentang mengatur jarak dengan orang lain. Pada kuesioner nomor 13, hasilnya $86,7 \%$ memilih setuju dan sangat setuju, dan 11,3\% memilih ragu-ragu. Angka ini cukup signifikan untuk menunjukkan bahwa mayoritas responden menerapkan jaga jarak secara langsung atau social distancing. Selain itu, pada indikator maintenance, hasil data yang diperoleh dari responden mendapatkan hasil yang sangat baik. Perolehan total responden (kuesioner nomor 16, 17, 18) yang memilih setuju dan sangat setuju menunjukkan angka $75,6 \%$, 92,9\%, dan $85,8 \%$ berturutturut menjelaskan tentang memesan 
makanan, menyediakan alat kebersihan di rumah, dan menghindari kegiatan di luar rumah. Pernyataan-pernyataan pada indikator maintenance ini mendukung penjelasan dari tim riset National Centre for Immunisation Research \& Surveillance dan School of Public Health \& Community Medicine, University of New South Wales (2015) yang menjelaskan langkah-langkah upaya social distancing seperti working from home (bekerja dari rumah) dan cancelletion of mass gatherings (pembatalan pertemuan yang bersifat masal). Angka yang diperoleh pada kuesioner bagian indikator maintenance juga menjelaskan bahwa mayoritas responden sadar akan pentingnya menghindari keramaian di luar rumah.

Berbeda dari penelitian-penelitian sebelumnya, penelitian ini menggunakan model stage of changes dari Schmied (2017) yang menjelaskan bagaimana perilaku social distancing responden setelah menerima stimulus (dalam penelitian ini video tentang 'corona' dari Bintang Emon sebagai pesan persuasi) dengan tahapan-tahapan yang lengkap mulai dari persiapan hingga ke tahapan dimana seseorang merasa melakukan perilaku social distancing adalah sebuah keharusan. Model stage of changes dari Schmied (2017) dengan tahapan perubahan perilaku yang kompleks, dapat digunakan untuk mengukur bagaimana atau sejauh mana perubahan perilaku responden dalam hal ini adalah perilaku social distancing.

Untuk mengetahui bagaimana korelasi antara variabel independen (X) terhadap variabel dependen (Y), maka dilakukan uji korelasi. Hasil dari perhitungan statistik dari data yang telah diperoleh dari responden menunjukkan bahwa kedua variabel pada penelitian ini berkorelasi dan signifikan. Nilai $r$ hitung yang diperoleh bernilai 0,303 yang artinya $>0,20$ sedangkan nilai signifikansi bernilai
$0,02<0,05$. Selain itu, pada uji regresi sederhana, data yang diperoleh dari responden mendapatkan hasil $\hat{Y}=50.348$ + 0.682X. Artinya, adalah nilai dari variabel dependen akan terus bertambah untuk setiap penambahan variabel independen. Dalam hal ini, artinya nilai perilaku social distancing akan bertambah apabila nilai koefisien dari variabel menonton video tentang 'Corona' bertambah.

Pada uji t-test didapatkan hasil bahwa nilai signifikansi analisis regresi sederhana sebesar 0,02 yang artinya < 0,05. Data ini didukung dengan nilai $t$ hitung 3.144 yang artinya lebih besar dari $\mathrm{t}$ tabel 1.988. Hasil dari perhitungan statistik ini semakin menjelaskan adanya pengaruh yang ditimbulkan dari menonton video tentang 'Corona' dari Bintang Emon terhadap perilaku social distancing dalam hal ini para responden yaitu Mahasiswa FPSB UII. Video DPO tetang 'Corona' yang dibuat oleh Bintang Emon memberikan dampak sesuai dengan isi pesannya yang mengajak masyarakat untuk melakukan upaya social distancing.

\section{KESIMPULAN}

Penelitian ini menyimpulkan bahwa menonton video tentang 'Corona' dari Bintang Emon memberikan pengaruh yang positif dan signifikan terhadap perilaku social distancing Mahasiswa FPSB UII. Hal ini dibuktikan pada analisis regresi linear sederhana yang menunjukkan nilai konstanta regresi untuk variabel menonton video tentang 'Corona' dari Bintang Emon sebesar 0,682. Artinya, setiap penambahan $1 \%$ penambahan nilai pada variabel menonton video tentang 'Corona' dari Bintang Emon, maka nilai perilaku social distancing akan bertambah sebesar 0,682 .

Pada uji regresi didapatkan hasil nilai signifikansi sebesar 0,02 yang artinya $>$ 0,05. Selain itu didapatkan nilai t hitung 
sebesar 3.144 > dari t tabel yang bernilai 1.988. Hasil ini menunjukkan bahwa adanya pengaruh yang diberikan variabel menonton video tentang Corona' dari Bintang Emon terhadap perilaku social distancing Mahasiswa FPSB UII. Dengan demikian, dapat disimpulkan bahwa pada penelitian ini hipotesis diterima.

Berdasarkan hasil penelitian tersebut, penelitian ini menyarankan agar para influencer mengambil peran lebih aktif dalam mendorong kepatuhan masyarakat. Para influencer dapat mendorong dipatuhinya protokol kesehatan, termasuk dalam hal ini social distansching, penggunaan masker, dan sebagainya. Dengan begitu, penyebaran virus Corona dapat ditekan semaksimal mungkin.

\section{DAFTAR PUSTAKA}

Arief, M. N. (2015). "Pengaruh Terpaan Media Televisi dan Komunikasi Peer Group Terhadap Minat Berhijab Gaya Dewi Sandra pada Mahasiswa DIII FE UII Yogyakarta” (Doctoral dissertation, Universitas Islam Indonesia).

Buana, D. R. (2020). "Analisis Perilaku Masyarakat Indonesia dalam Menghadapi Pandemi Virus Corona (Covid-19) dan Kiat Menjaga Kesejahteraan Jiwa. Salam: Jurnal Sosial dan Budaya Syar-i," 7(3), 217-226.

Bungin, B. (2006). Metode Penelitian Kuantitatif. Jakarta: Kencana Prenada Media Group.

Dimyati, S. A. (2019). "Pengaruh celebrity Endorser Melalui Sosial Media Instagram@wiwikk_Terhadap Brand Image dan Keputusan Pembelian Konsumen Brand Zoya" (Doctoral dissertation, Universitas Islam Indonesia).

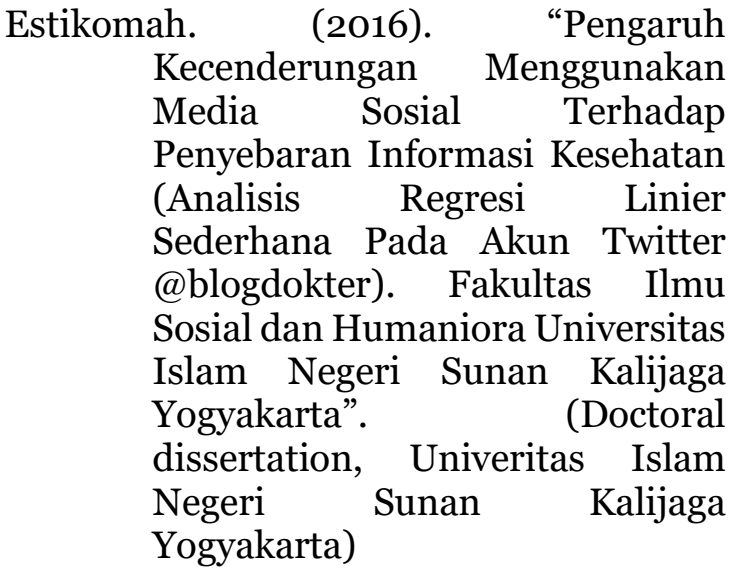

Frisnawati, A. (2013). "Hubungan antara intensitas menonton reality show dengan kecenderungan perilaku prososial pada remaja”. EMPATHY Jurnal Fakultas Psikologi, 1(1).

Halim, A. (2019). "Efektivitas penontonan Video Anti Narkoba Terhadap Pengetahuan Siswa Pada Bahaya Narkoba,(Studi Eksperimen Pada Siswa SMP Negeri 3 Siak Hulu Kabupaten Kampar).” (Doctoral dissertation, Universitas Islam Negeri Sultan Syarif Kasim Riau). 
Hamka, A. (2015). "Efek Video Tutorial Online Dalam Kegiatan Ekstrakurikuler Animasi Di SMKN 7 Samarinda.” EJournal Llmu Komunikasi, 3(3).

Hasibuan, S. A. (2015). "Pengaruh Menonton Model Jilbab Dalam Iklan Kosmetik Muslimah Wardah Terhadap Perilaku Memakai Jilbab Mahasiswi Jurusan Akuntansi Fakultas Ekonomi Universitas Ahmad Dahlan Yogyakarta." (Doctoral dissertation, Universitas Islam Negeri Sunan Kalijaga Yogyakarta).

Janie, D. N. A. (2012). Statistik deskriptif \& regresi linier berganda dengan SPSS. Jurnal, April.

Khoiriyah, N. M. (2019). "Pengaruh Terpaan Tayangan Horror Pada Channel Youtube "JurnalRisa" Terhadap Sikap Mahasiswa HMI FISIP Akan Hal-hal Mistis (Studi Pada Anggota Himpunan Mahasiswa Islam FISIP 20142018 Universitas Muhammadiyah Malang)." (Doctoral dissertation, University of Muhammadiyah Malang).

Kriyantono, R. (2012). Teknik Riset Komunikasi. Jakarta: Kencana.

Kurnia, N. (2005). "Perkembangan teknologi komunikasi dan media baru: Implikasi terhadap teori komunikasi." Mediator: Jurnal Komunikasi, 6(2), 291-296

Matondang, Z. (2009). Validitas dan reliabilitas suatu instrumen penelitian. Jurnal Tabularasa, 6(1), 87-97.

Muhson, A. (2006). Teknik analisis kuantitatif. Universitas Negeri Yogyakarta. Yogyakarta.

Munir, M. (2012). Multimedia konsep \& aplikasi dalam pendidikan. Bandung: Alfabeta.
Pamungkas, S. (2014). "Potensi Pengembangan Aplikasi Muktimedia Sebagai Media Komunikasi Persuasif Di Sosial Media. Jurnal Sosial Humaniora." (JSH), 7(1), 75-93.

Pamurgawati, Azizah. "Profil Bintang Emon, Juara Stand Up Comedy Academy 3." https://entertainment.kompas.co $\mathrm{m} / \mathrm{read} / 2020 / 03 / 23 / 193057866$ Lprofil-bintang-emon-juarastand-up-comedy-academy-3 (akses 28 November 2020)

Prawira, Adi. "Deretan Video DPO Bintang Emon Yang Viral Di Dunia Maya." https://www.kompas.com/hype/ $\mathrm{read} / 2020 / 05 / 08 / 110014266 / \mathrm{de}$ retan-video-dpo-bintang-emonyang-viral-di-dunia-

maya?page $=2 \quad$ (akses $\quad 28$

November 2020)

Priyono, D. MM. (2016). Metode Penelitian Kuntitatif. Sidoarjo: Zifatama Publishing.

Pujihastuti, I. (2010). Prinsip penulisan kuesioner penelitian. CEFARS: Jurnal Agribisnis dan Pengembangan Wilayah, 2(1), 43-56.

Putri, F. I., et. al. (2015). “Teknik-teknik Persuasif Dalam Media Sosial (Studi Analisis Isi Kualitatif Pada Akun Mentor Parenting Ayah Edy di YouTube)." Interaksi Online, 4(1).

Rahardyan, D. (2019). "Pengaruh Terpaan Iklan Sabun LifeBuoy Versi 'Cuci Tangan Sebelum Berbuka Puasa'Terhadap Perilaku Cuci Tangan Pada Siswa SD (Studi Pada Siswa SDI Mohammad Hatta Malang)." (Doctoraldissertation, University of Muhammadiyah Malang). 
Raharjo, Sahid. "Cara Melakukan Uji t

Parsial dalam Analisis Regresi

dengan SPSS.”

https://www.spssindonesia.com/

2014/02/cara-mudah-

melakukan-uji-t-dengan-

spss.html (akses 3 Maret 2021).

Sari, D. P., \& Sholihah'Atiqoh, N. (2020). "Hubungan Antara Pengetahuan Masyarakat Dengan Kepatuhan Penggunaan Masker Sebagai Upaya Pencegahan Penyakit Covid-19 Di Ngronggah.” INFOKES Journal, 10(1), 52-55.

Schmied, P. (2017). Behaviour change toolkit. People in Need (PIN).

Sugiyono. (2018). Metode Penelitian Kuantitatif, Kualitatif dan R\&D. Bandung: Alfabeta.

Wahyuni, Riris Ayu (2019). "Pengaruh Terpaan Web-series Berjudul Sore - Istri Dari Masa Depan Terhadap Kesadaran Pencegahan Diabetes Milletus Pada Usia Muda (Studi Pada Mahasiswa Ilmu Komunikasi Universitas Muhammadiyah Malang Angkatan 2015).” (Doctoral dissertation, University of Muhammadiyah Malang).
Wakefield, M. A., Loken, B., \& Hornik, R. C. (2010). "Use of mass media campaigns to change health behaviour. The Lancet." 376(9748), 1261-1271.

Watie, E. D. S. (2016). "Komunikasi dan media sosial (communications and social media)." Jurnal The Messenger, 3(2), 69-74.

Wijayanto, A. (2008). Analisis regresi linear sederhana. Semarang: Universitas Diponegoro.

Wilder-Smith, A., \& Freedman, D. O. (2020). "Isolation, quarantine, social distancing and community containment: pivotal role for oldstyle public health measures in the novel coronavirus (2019-nCoV) outbreak." Journal of travel medicine, 27(2), taaao20.

Yuliara, I. M. (2016). "Regresi linier sederhana." Fakultas Matematika Dan Ilmu Pengetahuan Alam Universitas Udayana 
Rachmat Arya Prayuda \& Puji Hariyanti

118 Jurnal Mahasiswa Komunikasi Cantrik 